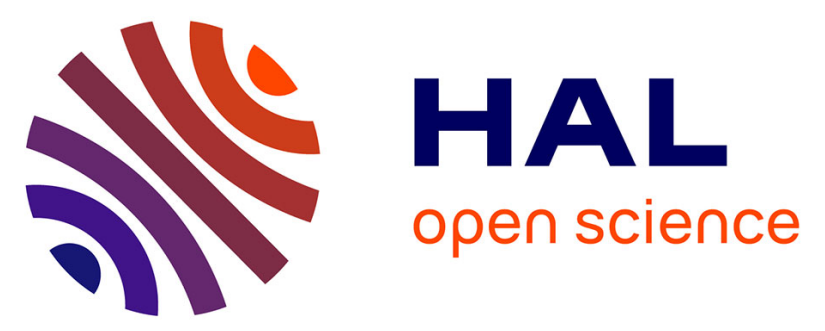

\title{
Isotope study on organic nitrogen of Westphalian anthracites from the Western Middle field of Pennsylvania (U.S.A.) and from the Bramsche Massif (Germany)
}

Magali Ader, Jean-Paul Boudou, Marc Javoy, Bruno Goffé, Eric Daniels

\section{To cite this version:}

Magali Ader, Jean-Paul Boudou, Marc Javoy, Bruno Goffé, Eric Daniels. Isotope study on organic nitrogen of Westphalian anthracites from the Western Middle field of Pennsylvania (U.S.A.) and from the Bramsche Massif (Germany). Organic Geochemistry, 1998, 29, pp.315 323. 10.1016/S01466380(98)00072-2 . bioemco-00156941

\section{HAL Id: bioemco-00156941 \\ https://hal-bioemco.ccsd.cnrs.fr/bioemco-00156941}

Submitted on 24 Jun 2007

HAL is a multi-disciplinary open access archive for the deposit and dissemination of scientific research documents, whether they are published or not. The documents may come from teaching and research institutions in France or abroad, or from public or private research centers.
L'archive ouverte pluridisciplinaire HAL, est destinée au dépôt et à la diffusion de documents scientifiques de niveau recherche, publiés ou non, émanant des établissements d'enseignement et de recherche français ou étrangers, des laboratoires publics ou privés. 


\title{
Isotope study on organic nitrogen of Westphalian anthracites from the Western Middle field of Pennsylvania (U.S.A.) and from the Bramsche Massif (Germany)
}

\author{
MAGALI ADER ${ }^{1 *}$, JEAN-PAUL BOUDOU ${ }^{2}$ MARC JAVOY $^{1}$, \\ BRUNO GOFFE ${ }^{3}$, ERIC DANIELS ${ }^{4}$ \\ ${ }^{1}$ Laboratoire de Géochimie des Isotopes Stables, CNRS URA 1762, Université Paris VII, 4 Place \\ Jussieu, 75251 Paris Cedex 05, France, \\ ${ }^{2}$ Laboratoire de Géochimie et Métallogenie, CNRS URA 1762. \\ Physicochimie des Fluides Géologiques, Case 124, Université Paris VI, 4 Place Jussieu, 75252 Paris \\ Cedex 05, France, \\ ${ }^{3}$ Laboratoire de Géologie, Ecole Normale Supérieure, 24, rue Lhomond, 75005 Paris. \\ France \\ ${ }^{4}$ Chevron Petroleum Technology Company, P.O. Box 446, La Habra, CA, U.S.A. 90633- \\ 0446
}

\begin{abstract}
The objective of this study was to examine an aspect of the thermal cycling of organic nitrogen in sediments and metasediments. The cycling of organic nitrogen is important because sedimentary organic matter is a shuttle of nitrogen from the atmosphere to the lower crust and thermal decomposition of organic matter is a critical step in the recycling of nitrogen between the different nitrogen pools. Abundance and isotopic composition of organic nitrogen were determined in the particular case of two low sulfur Westphalian anthracites series from Pennsylvania and Bramsche Massif. They represent good examples of Euramerica coals spanning the whole range of anthracitization in single fields. Gold cell experimental simulation of the denitrogenation process was conducted at moderate pressure to show that both suites make ideal metamorphic profiles without any shift due to change of facies or to hydrothermal disturbance. During anthracitization, organic nitrogen content decreases rapidly while organic nitrogen isotopic composition does not change with rank increase. The preservation of the isotopic signature implies that organic nitrogen isotopes could be used as indicators for the paleoecological and paleodepositional history reconstruction of the basins. The striking contrast between the rapid and sharp decrease of nitrogen organic content and the invariance of its isotopic composition during the whole anthracitization suggests that ammonia is an important product of the denitrogenation process. Key words nitrogen, isotope, anthracite, Pennsylvania, North Germany, metamorphism, coal, kerogen, gold cell
\end{abstract}

INTRODUCTION

Thermal nitrogen cycling in sediments and metasediments has received little attention. Variations of organic nitrogen content and of its isotopic composition with maturation remain largely unknown. However, since highly metamorphosed organic matter is supposed to contain only trace amounts of nitrogen, one can predict that nitrogen is released by sedimentary organic matter during diagenesis and metamorphism. Improvements of our knowledge about the fate of organic nitrogen in natural and experimental maturation series should lead to a better understanding of the process of denitrogenation and may help in using organic nitrogen isotopes to establish the distribution of nitrogen among various reservoirs in earth (Javoy et al.,

\footnotetext{
*To whom correspondence should be addressed. E-mail: ader(Opgp.jussieu.fr.

tE-mail: boudou@cicrp.jussieu.fr brunoWr euclase.ens.fr

\E-mail: ejda(achevron.com
}

1986; Zhang and Zindler, 1993; Bebout, 1995; Javoy, 1997).

The present study reports organic nitrogen abundance and isotopic composition during anthracitization. The objective is to investigate ideal metamorphic profiles of organic nitrogen from low vascular plants in two Westphalian anthracite suites.

\section{MATERIAL AND METHODS}

The samples are listed in Table 1 . The Western Middle anthracite field of Pennsylvania (U.S.A.) and the Bramsche Massif (Germany), paleobotanically dated as Westphalian (Middle Pennsylvanian), were chosen because the coals represent a wide range of rank from anthracite to meta-anthracite. Hence, the whole anthracitization could be easily observed in the same field. A second reason was that there is an abundance of background material available for the region, including geological, petrographical, geochemical syntheses and experimental simulation of coal anthracitization and graphitiza- 
Table I. Samples, rank, organic N abundance and isotopic composition

\begin{tabular}{|c|c|c|c|c|c|c|c|}
\hline Sample No & Source* & Field & Stratigraphy & $\mathrm{R},,,,,(\%)$ & $100 \mathrm{~N} / \mathrm{Ct}$ &, $\left.5^{15} \mathrm{~N}(\%)\right)$ & $6130(" X)$. \\
\hline \multicolumn{8}{|c|}{ Pennsylvania } \\
\hline WM-GP-M8-CH & JL & Mammoth\#8 & Mid. Penn. & 2.68 & 1.34 & 4.45 & -24.30 \\
\hline WM-ED-M9-CH & JL & Mammoth\#9 & Mid. Penn. & 2.97 & 1.43 & 4.65 & -23.50 \\
\hline WM-SH-M8-GR & JL & Mammoth\#8 & Mid. Penn. & 3.45 & 1.29 & 4.35 & -24.30 \\
\hline WM-RN-LO-CH & JL & Little Orch. & Mid. Penn. & 3.78 & 1.22 & 5.05 & -25.80 \\
\hline WM-CR-LY-CH & $\mathrm{JL}$ & Lykens & Mid. Penn. & 5.30 & 0.66 & 4.05 & -24.20 \\
\hline PSOC 1468 & PSOC & Buck Mtn & Mid. Penn. & 5.45 & 0.61 & 4.95 & -24.15 \\
\hline PSOC 870 & PSOC & Primrose & Mid. Penn. & 5.57 & 0.62 & 4.85 & -23.95 \\
\hline I6H & ED & Mammoth & Mid. Penn. & 5.66 & 0.67 & 4.75 & -24.40 \\
\hline $17 \mathrm{~A}$ & ED & Buck Mtn & Mid. Penn. & 5.74 & 0.69 & 5.35 & -23.50 \\
\hline $2 \mathrm{C}$ & ED & Buck Mtn & Mid. Penn. & 6.30 & 0.66 & 4.15 & -23.50 \\
\hline \multicolumn{8}{|c|}{ Bramsche } \\
\hline U150-7723 & AVR & Ibbenburen & Westfal. C & 2.91 & 1.00 & 2.80 & -24.10 \\
\hline U150-7796 & AVR & Ibbenburen & Westfal. B & 3.51 & 1.01 & 3.72 & -25.40 \\
\hline IB-115229 & BGR & Ibbenburen & Westfal. B & 4.22 & 0.92 & 3.05 & -23.70 \\
\hline IBW1-13493 & AVR & Ibbenburen & Westfal. B & 4.27 & 0.92 & 2.70 & -24.00 \\
\hline IBW2-14488 & AVR & Ibbenburen & Westfal. B & 4.72 & 0.98 & 3.00 & -23.30 \\
\hline PIES-751 & AVR & Piesberg & Westfal. D & 6.00 & 0.50 & 3.70 & -24.15 \\
\hline PIES-693 & BGR & Piesberg & Westfal. D & 7.00 & 0.40 & 3.60 & -24.05 \\
\hline PIES-6770 & AVR & Piesberg & Westfal. D & 7.14 & 0.41 & 3.45 & -24.92 \\
\hline
\end{tabular}

*JL: J. Levine, PSOC: Penn State Office of Coal Research, ED: E. Daniels, AVR: A. Vieth-Redemann (Geologishes Landesamt NRW), BGR: Bundesanstalt fur Geowissenschaften and Rohstoffe.

Organic NI/organic C, atomic ratio x 100.

tion (Teichmiiller and Teichmtiller, 1950; Hryckowian et al., 1967; Mundry, 1971; Stadler and Teichmtiller, 1971; Bunterbarth and Teichmiiller, 1979; Edmunds et al., 1979; Oleksyshyn, 1982; Levine and Davis, 1983, 1989; Philips et al., 1985; Daniels and Altaner, 1990, 1993; Levine and Eggleston, 1992; Wilks et al., 1993; Daniels et al., 1994; Bustin et al., 1995).

Pennsylvanian coal samples were collected from outcrops and strip mines. Bramsche Massif samples were collected from the coal mines of Ibbenburen and Piesberg. In order to avoid any change of paleodepositional facies along the anthracitization sequence, only samples with low sulfur content $(<1 \%)$ were selected for the study. Low-sulfur coal indicates particular paleogeographical-sedimentological origin and non-marine post-depositional geochemistry. Acid conditions during the peat stage of coal formation should result in leaching of acid-soluble elements, as well as inhibiting sulfur fixation and microbial degradation of organic matter (Westgate and Anderson, 1984; Cecil et al., 1985).

Vitrinite reflectance measurements and elemental analysis of crude samples were performed according to Stach et al. (1982), Levine and Davis (1983), Daniels and Altaner (1990, 1993) and Daniels (1992). Organic matter was isolated using HF/HC1 digestion of the mineral matter in a Prolabo microwave digestor (Microdigest 301). Isotopic analyses of the organic matter were made using a Finnigan DeltaE mass spectrometer and were reported in the "delta" notation: per mil, relative to the Pee Dee Belemnite Standard $\left(6^{13} \mathrm{C}\right)$ and relative to the atmospheric nitrogen $\left(6^{i} \mathrm{~N}\right)$. Nitrogen samples were prepared using combustion in quartz tubes with $\mathrm{CuO}, \mathrm{Cu}$ and $\mathrm{CaO}$ in order to trap $\mathrm{CO}_{2}$ and $\mathrm{H} 20$ (Kendall and Grim, 1990; Boyd et al., 1994; Boyd et al., 1995). Evacuation on a vacuum line proceeded as follows: $\mathrm{CuO}, \mathrm{Cu}$ and $\mathrm{CaO}$ were degassed for $4 \mathrm{~h}$ at $600^{\circ} \mathrm{C}$, then powdered sample was added and conditioned at $300^{\circ} \mathrm{C}$ for $2 \mathrm{~h}$. The loaded and pretreated tube was then flame sealed, combusted at $950^{\circ} \mathrm{C}$ for $4 \mathrm{~h}$, cooled at $600^{\circ} \mathrm{C}$ for $3 \mathrm{~h}$ to allow (i) residual oxygen to recombine with cupric oxide, (ii) nitrous oxide to be reduced by copper and (iii) carbon dioxide to be trapped by $\mathrm{CaO}$. Then the tubes were slowly cooled to ambient temperature allowing water to combine with $\mathrm{CaO}$. The quartz tube was opened on a vacuum line with a tube cracker. The combustion gases were cooled to liquid nitrogen temperature. Using a Toepler pump, the purified nitrogen was concentrated in a calibrated volume allowing quantification. Possible contamination was checked by scanning of $m / z 12,15,16,30,32$ and 40 (Ar). Samples for $\left(5^{13} \mathrm{C}\right.$ determination were prepared in a similar but simpler way: no $\mathrm{CaO}$ was added to the combustion tube and the $\mathrm{CO}_{2}$ was separated cryogenically using a liquid nitrogen trap. Precision for $\mathrm{O}^{\prime} \mathrm{N}$ was $+0.15 \% 0$ and for $13 \mathrm{C}+0.05 \%$ o.

\section{RESULTS AND DISCUSSION}

Variation of organic nitrogen content with maturation

In Fig. 1, the atomic N/C ratio of organic matter is expressed with respect to vitrinite reflectance between $-R,,,, 2.5$ and $7.5 \%$. The organic N/C 


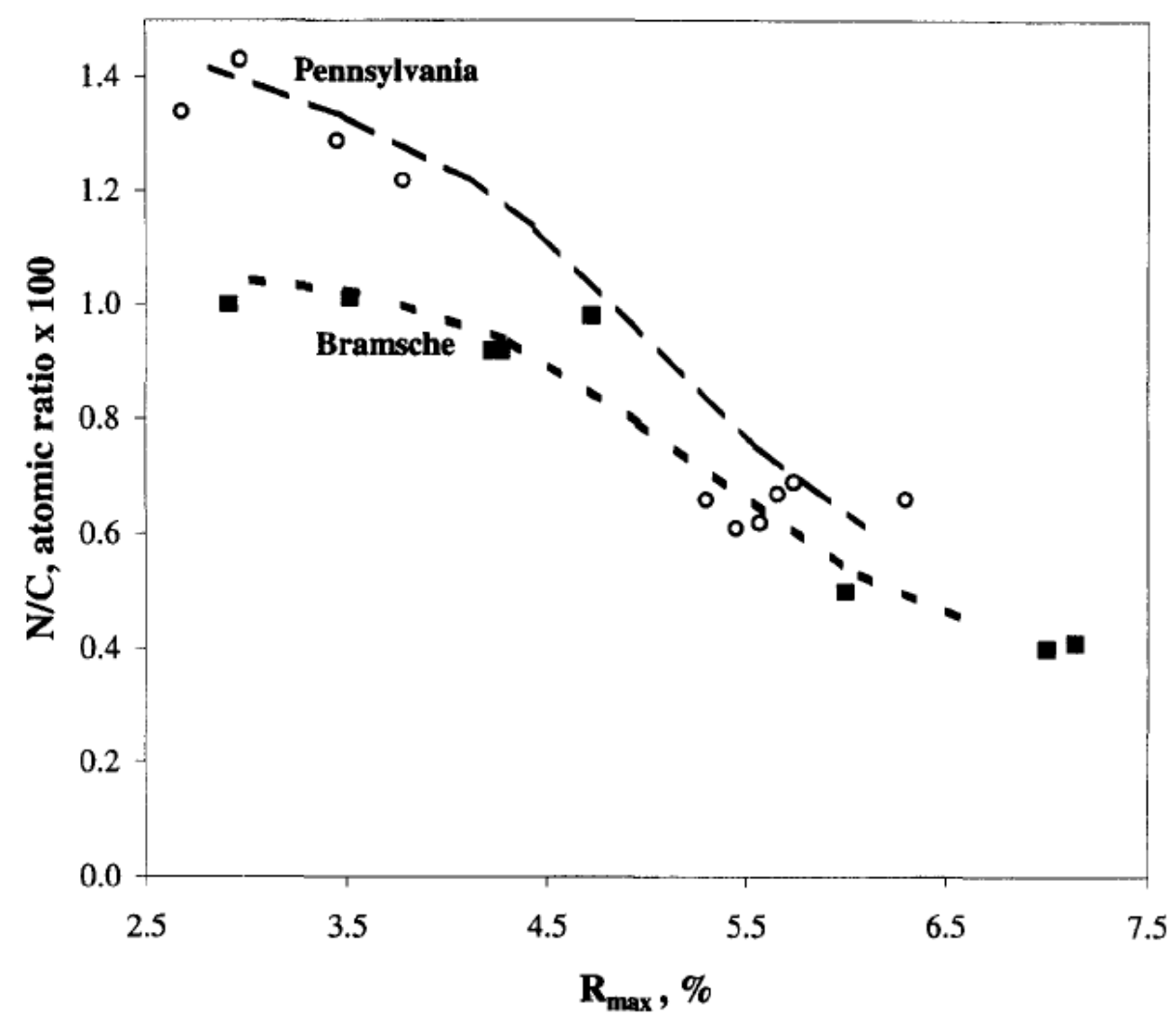

Fig. 1. Organic nitrogen abundance vs $R_{\max }$ for Pennsylvania and Bramsche natural samples.

(x100) for the Pennsylvanian coals decreases from -1.4 to 0.6 (at $R_{\max } 6 \%$ ) whereas for Bramsche coals N/C (x100) the range is lower and decreases from -1.0 to 0.4 (at $\mathrm{Rmax}^{2} \%$ ). The decreasing organic N/C with rank for the Ibbenbiiren/Piesberg series is here reported for the first time. Similar rapid organic N/C decrease above -,,$R_{\max } 4.5 \%$ was also reported, but not commented on, by Volkova and Bogdanova (1989) in the Donetz anthracite and meta-anthracite suite. A few authors, who claim that total nitrogen is an acceptable substitute for organic nitrogen, also reported a decreasing trend in the late stages of coalification: Suggate (1959) on NewZealand coals (who wrote that "further information is clearly required" to provide an adequate justification of the observed trends), Shapiro and Gray (1966) on Antarctic coals, Drechsler and Stiehl (1977) on German anthracites, Paxton (1983) on the Pennsylvanian anthracite field and Burchill and Welch (1989) on the British coals. More recently, Littke et al. (1995) showed a very weak decrease of the total $\mathrm{N}$ content in a series of 3 anthracites and 2 meta-anthracites from several origins. These repeated observations tend to support the validity of a general interpretative scheme where the main loss of organic nitrogen occurs in the very late stage of coalification (Boudou et al., 1984; Boudou and Espitalie, 1995).
Organic nitrogen isotopic composition as a tracer of origin

Previous works (Peters et al., 1978; Mariotti, 1982; Rigby and Batts, 1986; Scholten, 1991) have assessed the potential of ${ }^{15} \mathrm{~N} /{ }^{14} \mathrm{~N}$ ratio as indicator of sedimentary environment. In the Pennsylvania and Bramsche Massif suites, $\left(5^{15} \mathrm{~N}\right.$ as well as $(513 \mathrm{C}$ do not change systematically with rank (Table 1$)$, but anthracites display two narrow ranges of $(515 \mathrm{~N}$ values: Pennsylvanian $\left(5^{15} \mathrm{~N}\right.$ values range from 4.1 to $5.4 \%$ o and Bramsche values range from 2.7 to $3.7 \% 0$ (Fig. 2). As expected, there is no $8^{13} \mathrm{C}$ shift during maturation (Galimov, 1980; Lewan, 1986). The present paper shows, for the first time, that in the particular case of sedimentary organic matter from lower vascular plants, organic nitrogen isotopic composition does not change during metamorphism (until $-\mathrm{R}_{\mathrm{ma}}, 7 \%$ ), from anthracite (PP facies) to meta-anthracite rank (greenschist facies, Kish, 1987). In the case of Northern Germany, Gerling et al. (1997), studying the total nitrogen, presented similar results to ours for the anthracite stage (until ${ }^{R} \max 4 \%$ ), it means for the less important stage of coal denitrogenation where inorganic nitrogen content is still very low (Daniels and Altaner, 1990, 1993). Our results add substance to the argument of Haendel et al. (1986) who had 


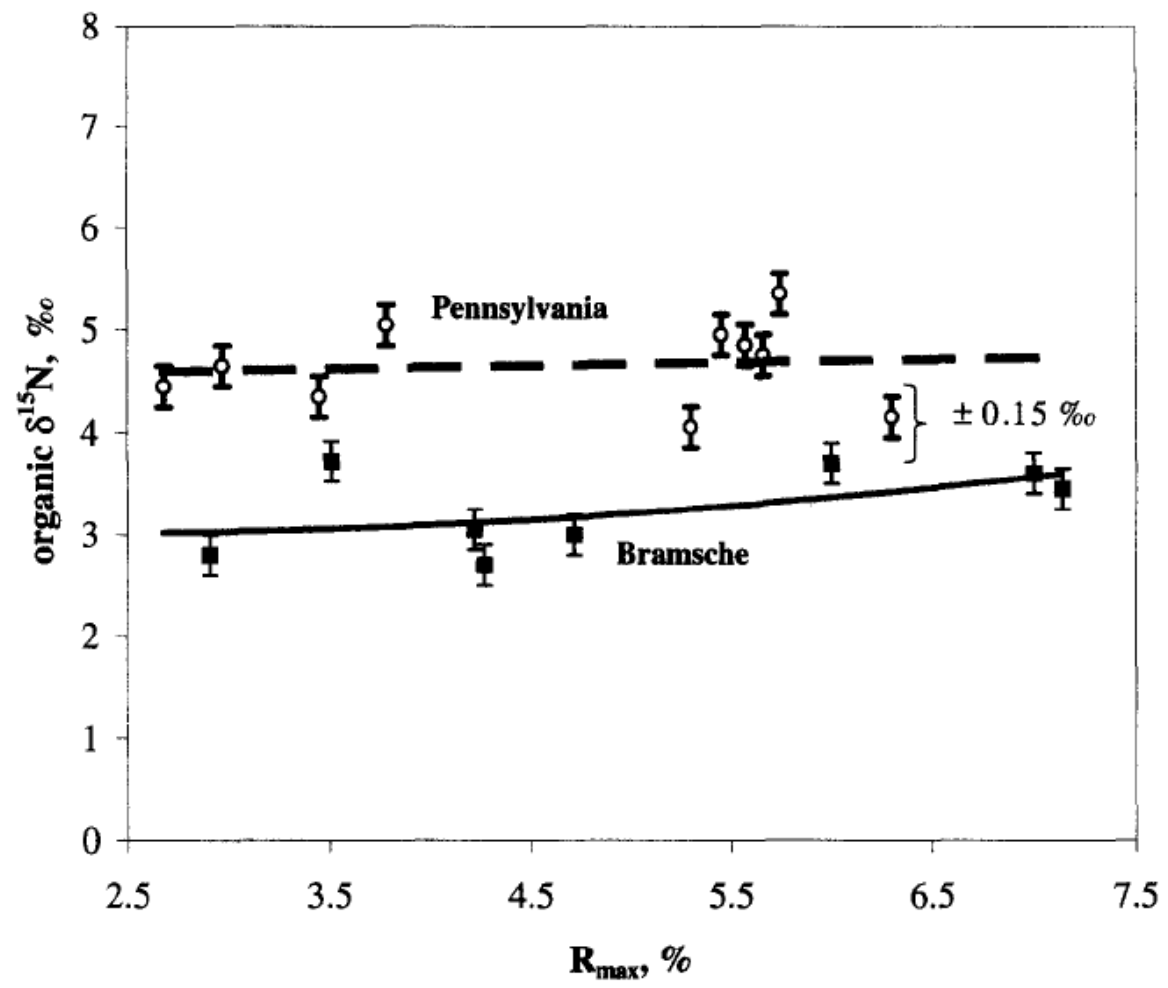

Fig. 2. $\delta^{15} \mathrm{~N}$ of organic nitrogen vs $R_{\max }$ for Pennsylvania and Bramsche natural samples.

assumed that a leveling of the nitrogen isotope composition would take place during diagenesis up to the boundary of greenschist facies.

Slight differences of organic $\mathrm{N}$ content and $(515 \mathrm{~N}$ in both anthracite suites (Pennsylvania and Bramsche) are thought to reflect the similarities and slight differences of the paleophytogeography and the paleoclimate of the two basins, at a time of maximum assembly of Pangaea drifting northward (Scotese et a!., 1979). These facts would be in conformity with the paleobotanical results of Philips et al. (1985) who wrote that regional differences in tectonic setting, historical aspects of the vegetation and local environmental differences may make the patterns of vegetational change somewhat different in each coal region. The drastic changes in coalswamp vegetation are transitional across the Middle-Upper Pennsylvanian boundary and are very similar in each of the major coal regions of the United States and Europe. However, an important difference between the vegetation on either side of the Appalachians is the continued presence of some Lycospora-bearing Lycopods in Europe. This is possibly the result of a more asymmetric change in the drying of the climate there (Hedemann and Teichmiiller, 1971). The slight differenciation of the Pennsylvanian and of the Bramsche anthracite suites on the basis of organic nitrogen isotopes shows that nitrogen isotope data may be a significant indicator of the precursor flora, the environment of deposition and the type and degree of alteration of the plant substances. This differentiation should be explained by further studies on the paleoecology of both coal-bearing depositional systems following the approach of Altebdumer (1983), Wnuk (1985, 1989), Wnuk and Pfefferkorn (1987) and Diessel (1992).

\section{Experimental simulation}

Since there is no valid method to experimentally simulate the natural metamorphism starting with an immature coal (Wilks et a!., 1993), the simulation was done with an anthracite sample taken at the onset of the denitrogenation window (anthracitization and further graphitization). The simulation was conducted under hydrostatic pressure because the role of tectonic shearing on anthracitization has not yet been put in evidence (Levine, 1993). Moderate hydrostatic pressure $(0.2 \mathrm{GPa})$ was chosen because high pressure may have a suppressing effect on maturation (Goffe and Villey, 1984; Domine, 1987; Dalla Torre et al., 1997). The anthracite sample, the temperature and pressure conditions were chosen according to our previous work on open system pyrolysis (Boudou and Espitalie, 1995), gold cell experiments previously performed by Hryckowian et 
Table 2. Analysis of anthracite sample WM-GP-M8-CH

\begin{tabular}{lccc}
\hline & \% As received & \% Dry & \% Dry ash free \\
\hline H20 & 1.47 & & \\
Volatile matter & & 9.97 & \\
Fixed carbon & 74.82 & \\
Ash & 15.21 & \\
BTU* & 12869 & \\
C & & 90.9 \\
H & & 3.74 \\
N & & 1.42 \\
& & 0.98 \\
(by difference) & & 2.94 \\
*British Thermal Unit per pound. &
\end{tabular}

a!. (1967) and some preliminary experiments using isostatic pressure by means of an anvil press (Boudou et al., 1997). Being the least mature anthracite of the Pennsylvanian series, anthracite sample WM-GP-M8-CH from the Middle Mammoth seam (Hryckowian et a!., 1967; Levine and Davis, 1983) was chosen for the gold cell experiment. Its main characteristics, given by Levine and Davis (1983), are presented in Table 2. The sample was heated at $600^{\circ} \mathrm{C}, 0.2 \mathrm{GPa}$ for 15 days, in a sealed gold cell (Domine, 1987). Hryckowian et al. (1967), who performed gold cell experiments with an anthracite sample from the same coal seam as WMGP-M8-CH, had observed that $600^{\circ} \mathrm{C}$ is critical in reactions producing a rapid increase of reflectance and a fusion of the material to form a hard compact mass that we effectively observed in our experiments. The gold cell simulation, performed in our laboratory, showed that organic $\mathrm{N}$ content decreases while $6{ }^{13} \mathrm{C}$ and $S^{5} N$ of the organic matter remain unchanged (Fig. 3 and Table 3 ). These changes are similar to those observed in the natural series (Figs 1 and 2, Table 1). The constancy of the
Table 3. Effect of the gold cell experimental simulation on the organic atomic N/C ratio, $6{ }^{15} \mathrm{~N}$ and $6{ }^{13} \mathrm{C}$ of the WM-GP-M8-CH anthracite

\begin{tabular}{lccl}
\hline Experimental conditions & $\mathrm{N} / \mathrm{C}$ & $615 \mathrm{~N}(\% 0)$ & $6^{3} \mathrm{C}(\% 0)$ \\
\hline Initial sample & 1.34 & 4.45 & -24.30 \\
Gold cell, $600^{\circ} \mathrm{C}, 0.2 \mathrm{GPa}$, & 0.77 & 4.40 & -24.35 \\
$360 \mathrm{~h}$ & & & \\
\hline
\end{tabular}

$6{ }^{15} \mathrm{~N}$ suggests that denitrogenation, in confined system, as well as in nature, involves other reactions than in open system pyrolysis, where $6{ }^{15} \mathrm{~N}$ increases (Drechsler and Stiehl, 1977). The experimental work of Katritzky et al. (1995), Everlien (1997) and Gerling et al. (1997) suggests that pressured water, which, in our study, may result from anthracite degradation as well as from clay paragenesis, might play a denitrogenating role. Water, in a sealed capsule, as well as in hydrous pyrolysis experiments, would have an hydrogenating role (Huang, 1996; Everlien, 1997; Lewan, 1997). Wintsch et a!. (1981) propose coal hydrogenation by pressured neoformed molecular hydrogen as an important step in the mechanism of graphitization, consequently of denitrogenation.

Organic nitrogen isotopes as tracers of the mechanism of denitrogenation

Because it takes less energy to break $14 \mathrm{~N}-12 \mathrm{C}$ bonds than ${ }^{15} \mathrm{~N}-{ }^{\mathrm{I}} \mathrm{C}$ bonds, thermocracking of $\mathrm{N}$ $\mathrm{C}$ bonds should produce a preferential release of 14N (Bigeleisen, 1965; Melander and Saunders, 1980). As a result, if denitrogenation involved thermal breaking of a high energy bond, it should lead to a strong enrichment of the heavier nitrogen isotope (Drechsler and Stiehl, 1977; Haendel et a!., 1986; Bebout and Fogel, 1992). The present study

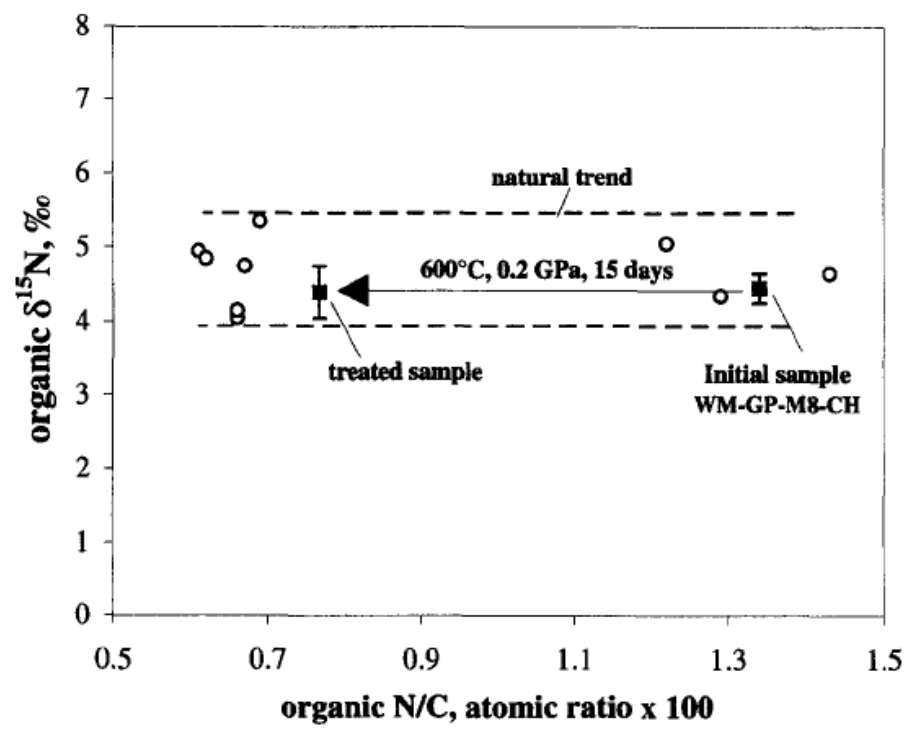

Fig. 3. Results of gold cell experimental simulation with the Pennsylvania WM-GP-M8-CH sample at $600^{\circ} \mathrm{C}$ and $0.2 \mathrm{GPa}$ during 15 days (average of 2 runs). $\mathrm{O}$ : natural Pennsylvania samples (Table 1). 
shows that $6{ }^{15} \mathrm{~N}$ of organic nitrogen does not change with rank despite the $\mathrm{N} / \mathrm{C}$ ratio falling to half of its original value. Assuming that ammonia has been produced by irreversible reactions without any isotopic fractionation (Williams et al., 1995; Shearer and Kohl, 1993) and that molecular nitrogen derived from organic matter has a low $815 \mathrm{~N}$ (Boigk et al., 1976; Prasalov et al., 1990), it comes that molecular nitrogen would not be an important primary product of the anthracite denitrogenation. After Sohns et al. (1994), the Boigk et al. (1976) data show systematic deviation from the true values, as a result of air contamination for a sample with very low nitrogen concentration, of incomplete combustion of hydrocarbons, of fluctuation amounts of oxygen in the ion source due to contamination with air, etc. However, new stable nitrogen isotope ratio by GC/IRMS (Sohns et al., 1994; Gerling et al., 1997) still show that light nitrogen predominates $\left(6^{15} \mathrm{~N}\right.$ ranging from -9 to $\left.+3 \% 0\right)$ in the area adjacent to the intrusives of the Bramsche massif, where the rocks reach maturity above 12, ,", $4 \%$. Therefore, ammonia with higher $6{ }^{15} \mathrm{~N}$ should be an important primary product of the denitrogenation process. This interpretation does not preclude a direct co-genesis of molecular nitrogen from coal (Krooss et al., 1995), a generation of molecular nitrogen from a secondary decomposition of ammonia (Rohrback et al., 1983) or a mixing of $\mathrm{N}$, from several sources (Muller et al., 1973; Gerling et al., 1997). In deep sedimentary basins, where the redox potential is low, $\mathrm{NH}_{4}{ }^{+}$, which would find its way in the illite/muscovite interlayers, is the most stable form of aqueous nitrogen, unless an oxidizing catalytic agent is encountered along the path that produces N2 (Getz, 1976, 1981; Hallam and Eugster, 1976; Everlien and Hoffmann, 1991). In fact, Daniels and Altaner (1990, 1993), showed, in the case of the Pennsylvanian anthracite field, that the organic matter dispersed in the shale and concentrated in nearby coal seams releases nitrogen in connate brine in the form of aqueous ammonium. Authigenic $\mathrm{NH}_{4}$-rich illite forms by high temperature reaction of ammonia, derived from maturation of locally abundant organic matter, with kaolinite Cluster et al., 1987). The postulated hydrothermal fluids that flowed through some joints in the anthracite appear to have been enriched in $\mathrm{Mg}, \mathrm{Fe}$ and other transition elements. They are responsible for forming some unusual ordered mixed-layer clay minerals, such as tosudite, sudoite and rectorite. These brines do not appear to have carried ammonium into authigenic minerals, such as $\mathrm{NH}_{4}-\mathrm{il}$ lite and pyrophyllite. Rather, these minerals occur in closed, low permeability environments in the shale and coal matrix and sporadically in some joints sets. All elements in $\mathrm{NH}_{4}-$ illite and pyrophyllite are easily derived from the rock matrix itself.
CONCLUSIONS

The study of organic nitrogen abundance and isotopic composition in Upper Carboniferous anthracite suites of Pennsylvania (U.S.A.) and of the Bramsche Massif (Germany) brings the following results:

(1) The data presented confirm earlier reports that the organic nitrogen content decreases rapidly from anthracite to higher rank.

(2) Contrarily to nitrogen content, the organic nitrogen isotopic composition does not change with rank and hence could not be used as indicator of metamorphism.

(3) Slight differences of $\mathrm{S}^{\prime} \mathrm{N}$ in both anthracite suites may reveal differences of the paleophytogeography and the paleoclimate of the two basins.

(4) Sealed gold cell experimentation reproduces the behavior of organic nitrogen with rank increase: rapid decrease of $\mathrm{N}$ content and persistence of nitrogen isotope composition as well as carbon isotope composition.

(5) The rapid denitrogenation and the invariance of $\mathrm{N}$ isotope composition in both anthracite suites suggest that ammonia might be an important product of the denitrogenation process in the late stages of coalification.

Acknowledgements-The authors wish to thank Dr Jeffrey Levine, Consulting geologist, Tuscaloora, Alabama, for providing some Pennsylvannian anthracites and for helpful discussion and encouragement on our efforts to further understand the processes of deep gas formation. Angelika Vieth-Redemann from Geologisches Landesamt, Krefeld and Bundesanstalt far Geowissenschaften und Rohstoffe, Hannover are gratefully acknowledged for supplying the samples from the Bramsche Massif. The authors thank Professor A. Mariotti (Laboratoire de Biogeochimie des Isotopes Stables, Universite Paris VI) for the replication of some isotopic analyses presented in the paper and E. Petit (Laboratoire de Geochimie des Isotopes Stables, Universite Paris VII) for his assistance with the $6{ }^{13} \mathrm{C}$ determination. Many thanks also to PROLA BO (France) for the Microdigest 301 apparatus used in this work. The critical reviews of the manuscript by $\mathrm{Dr}$ B. H. Horsfield (editorial), Dr B. M. Krooss and Dr E. Faber were greatly appreciated.

\section{REFERENCES}

Altebdumer, A. M. (1983) Geochemische Untersuchungen zur Klarung der Fazies sowie der primal-en Migration auf Menge und Zusammensetzung des organischen Materials im Ft\& Katharina (Westfal A) und in den hangenden Schiefertonen (Westfal B) im Ruhrgebiet. Dissertation, Technische Hochschule Aachen.

Bebout, G. E. and Fogel, M. (1992) Nitrogen-isotope composition of metasedimentary rocks in the Catalina Schist, California: Implications for metamorphic devolatilization history. Geochimica et Cosmochimica Acta 56, 2839-2849.

Bebout, G. E. (1995) The impact of subduction-zone metamorphism on mantle-ocean chemical cycling. Chemical Geology 126, 191-2849.

Bigeleisen, J. (1965) Chemistry of isotopes. Science 147, 463-471. 
Boigk, H., Hagemann, H. W., Stahl, W. and Wollanke, G. (1976) Isotopenphysikalische Untersuchungen zur Herkunft und Migration des Stickstoffs nordwestdeutscher Erdgase aus Oberkarbon und Rotliegend. Erdol und Kohle, Erdgas, Petrochemie vereignit mit Brennstoff und Chemie 29, 103-112.

Boudou, J. P., Mariotti, A. and Oudin, J. L. (1984) Unexpected enrichment of nitrogen during the diagenetic evolution of sedimentary organic matter. Fuel 60, 430431.

Boudou, J. P. and Espitalie, J. (1995) Molecular nitrogen from coal pyrolysis. Kinetic modeling. Chemical Geology 126, 319-333.

Boudou, J. P., Ader, M., Javoy, M., Besson, J. M. and Syfosse, G. (1997) Etude experimentale du comportement sous haute pression de l'azote organique sedimentaire. ler Forum de Technologie des Hautes Pressions. La Londe les Maures, France.

Boyd, S. R., Rejou-Michel, A. and Javoy, M. (1994) Noncryogenic purification of subnanomole quantities of nitrogen gas for isotopic analysis. Analytical Chemistry 66, 1396-1402.

Boyd, S. R., Rejou-Michel, A. and Javoy, M. (1995) Improved techniques for the extraction, purification and quantification of nanomole quantities of nitrogen gas: the nitrogen content of diamond. Measurement Science Technology 6, 297-305.

Bunterbarth, G. and Teichmiiller, R. (1979) Zur Ermittlung des Paldotemperatur im Dach des Bramscher Intrusivs aufgrund von lnkohlungsdaten. Fortschritte in der Geologic von Rheinland und Westfalen 27, 171-182.

Burchill, P. and Welch, L. S. (1989) Variation of nitrogen content and functionality with rank for some U.K. bituminous coals. Fuel 68, 100-104.

Bustin, R. M., Ross, J. V. and Rouzaud, J. N. (1995) Mechanisms of graphite formation from kerogen: experimental evidence. International Journal of Coal Geology 28, 1-36.

Cecil, C. B., Stanton, R. W., Neuzil, S. G. N., Dulong, F. T., Ruppert, L. F. and Pierce, B. S. (1985) Paleoclimate controls on Late Paleozoic sedimentation and peat formation in the central Appalachian basin (U.S.A.). International Journal of Coal Geology 5, 195-230.

Dalla Torre, M., Mahlmann, R. F. and Ernst, W. G. (1997) Experimental study on the pressure dependence of vitrinite maturation. Geochimica et Cosmochimica Acta 61, 2921-2928.

Daniels, E. J. (1992) Nature and origin of minerals in anthracite from Eastern Pennsylvania. Ph. D. dissertation, Illinois University.

Daniels, E. J. and Altaner, P. (1990) Clay mineral authigenesis in coal and shale from the Anthracite region, Pennsylvania. American Mineralogist 75, 825-839.

Daniels, E. J. and Altaner, S. P. (1993) Inorganic nitrogen in anthracite from Eastern Pennsylvania, U.S.A.. International Journal of Coal Geology 22, 21-35.

Daniels, E. J., Aronson, J. L., Altaner, S. P. and Clauer, N. A. F. (1994) Late Permian age of $\mathrm{NH}_{4}$-bearing illite in anthracite from Eastern Pennsylvania, temporal limits on coalification in the Central Appalachians. Geological Society of America Bulletin 106, 760-766.

Diessel, C. F. K. (1992) Coal-hearing Depositional Systems. Springer Verlag, $721 \mathrm{p}$.

Domine, F. (1987) Influence de la pression et de la temperature sur la cinetique de pyrolyse d'hydrocarbures purs. Etude experimentale et simulation numerique. Implications geochimiques. Ph. D. dissertation, Universite Pierre et Marie Curie.

Drechsler, V. M. and Stiehl. G. (1977) Stickstoflisotopenvariationen in organischen Sedimenten. Chemie der Erde 36, 126-138.
Edmunds, W. E., Berg, T. M., Sevon, W. D.. Piotrowski, R. C. Heyman, L. and Rickard, L. Y., (1979) The Mississippian and Pennsylvanian (Carboniferous) Systems in the United States: Pennsylvania and New York (Carboniferous). U.S. Geological Survey, Professional Papers 1110-B, $33 \mathrm{p}$.

Everlien, G. and Hoffmann, U. (1991) Nitrogen in natural gas. Erdeil und Kohle, Erdgas, Petrochemie/Hydrocarbon Technology 44, 166-172.

Everlien, G. (1997) Hydrous pyrolysis of high-maturity Paleozoic coals and black shales from Central Europe and Adjacent areas: Thermodynamic considerations. Geologisches Jahrbuch D103, 43-64.

Galimov, E. M. (1980) $\mathrm{C}^{13} / \mathrm{C}^{\prime 2}$ in kerogen. In Kerogen, ed. B. Durand, pp. 271-300. Editions Technip, Paris.

Gerling, P., Idiz, E., Everlien, G. and Sohns, E. (1997)

New aspects on the origin of nitrogen in natural gas in

Northern Germany. Geologisches Jahrbuch D103, 65-85.

Getz, F. A. (1976) Molecular nitrogen: clue in coal-derivedmethane hunt. The Oil and Gas Journal 25, 220221.

Getz, F. A. (1981) $\mathrm{CH}_{4} / \mathrm{N}_{2}$-ratio in Northwest German Basin. Enid' und Kohle, Erdgas, Petrochemie veriegnit mit Brennstoff und Chemie 34, 508.

Gaffe, B. and Villey, M. (1984) Texture d'un materiel carbone implique dans un metamorphisme haute pressionbasse temperature (Alpes francaises). Les hautes pression influencent-elles la carbonification? Bulletin de Mineralogie 107, 81-91.

Hallam, M. and Eugster, H. P. (1976) Ammonium silicate stability relations. Contributions to Mineralog ${ }^{y}$ and Petrology 57, 227-244.

Haendel, D., Male, K., Nitzsche, H. M., Stiehl, G. and Wand, U. (1986) Isotopic variations of the fixed nitrogen in metamorphic rocks. Geochimica et Cosmochimica Acta 50, 749-758.

Hedemann, H. A. and Teichmuller, R. (1971) Le developpement paleogeographique $\mathrm{du}$ Carbonifere superieur. Fortschritte in der Geologic von Rheinland und Westfalen 19, 134-147.

Hryckowian, E., Dutcher, R. R. and Dachille, F. (1967) Experimental studies of anthracite coals at high pressures and temperatures. Economic Geology Series 62, 517-539.

Huang, W. L. (1996) Experimental study of vitrinite maturation: effects of temperature, time, pressure. water and hydrogen index. Organic Geochemistry 24, 233-241.

Javoy, M. (1997) The major volatile elements of the earth: their origin, behavior and fate. Geophysical Research Letters 24, 177-180.

Javoy, M., Pineau, F. and Delorme, 1-1. (1986) Carbon and nitrogen isotopes in the mantle. Chemical Geology 57, 41-62.

Juster, T. C., Brown, P. E. and Bailey, S. W. (1987) NH4bearing illite in very low-grade metamorphic rocks associated with coal, northeastern Pennsylvania. American Mineralogist 72, 555-565.

Kendall, C. and Grim, E. (1990) Combustion tube method for measurement of nitrogen isotope ratio using calcium oxide for total removal of carbon dioxide and water. Analytical Chemistry 62, 526-529.

Kish, H. J. (1987) Correlation between indicators of very low-grade metamorphism. In Low Temperature Metamorphism, ed. M. Frey, pp. 227-300. Blackie, Glasgow, London.

Katritzky, A. R., Shipkova, P. A., Allin, S. M., Barcock, R. A., Siskin, M. and Olmstead, N. (1995) Aqueous hightemperature chemistry. 22. Nitrogen-containing heterocycles in supercritical water at $460^{\circ} \mathrm{C}$. Energy and Fuels 9, 580-589.

Krooss, B. M., Littke, R., Muller, B., Frielingsdorf, J., Schowochau, K. and Idiz, E. F. (1995) Generation of 
nitrogen and methane from sedimentary organic matter: implications on the dynamics of natural gas accumulations. Chemical Geology 126, 291-318.

Levine, J. R. and Davis, A. (1983) Tectonic history of coal-hearing sediments in Eastern Pennsylvania using coal reflectance anisotropy. Special Research Report SR-118, Coal Research Section, The Pennsylvania State University, University Park, Pennsylvania 16802, 323 p.

Levine, J. R. and Davis, A. (1989) Reflectance anisotropy of Upper Carboniferous coals in the Appalachian foreland basin, Pennsylvania, U.S.A.. International Journal of Coal Geology 13, 341-373.

Levine, J. R. and Eggleston, J. R. (1992) The anthracite basins of Eastern Pennsylvania. 1992 Joint Meeting of the International Committee for Coal and Organic Petrology and The Society for Organic Petrology, 72 p. The Pennsylvania State University, University Park, Pennsylvania 16802.

Levine, J. R. (1993) Coalification: the evolution of coal as source rock and reservoir rock for oil and gas. In Hydrocarbons from Coal, eds. B. E. Law and D. D. Rice. Studies in Geology Series 38, 39-77. American Association of Petroleum Geologists.

Lewan, M. D. (1986) Stable carbon isotope of amorphous kerogens from Phanerozoic sedimentary rocks. Geochimica et Cosmochitnica Acta 50, 1583-1591.

Lewan, M. D. (1997) Experiments on the role of water in petroleum formation. Geochimica et Cosmochimica Acta 61, 3691-3723.

Littke, R., Krooss, B. M., Idiz, E. F. and Frielingsdorf, J. (1995) Molecular nitrogen in natural gas accumulations: generation from sedimentary organic matter at high temperatures. American Association of Petroleum Geologists Bulletin 79, 410-430.

Muller, E., Goldbecher, K., Botnewa, G. and Botnewa, T. A. (1973) Zur Geochemie und Genese stickstoffreicher. Erdgase Zeitschrift fur Angewandte Geologie 19, 494499.

Mariotti, A. (1982) Apports de la geochimie isotopique la connaissance du cycle de l'azote Ph.D. dissertation,

Universite Pierre et Marie Curie.

Melander, L. and Saunders, W. H. (1980) Reaction Rates of Isotopic Molecules. John Wiley and Sons, p. 333. Mundry, E. (1971) Der Temperaturverlauf im Dach des Bramscher Massives nach der Warmeleitungs-Theorie. Fortschritte in der Geologic von Rheinland und Westfalen 18, 539-546.

Oleksyshyn, J. (1982) Fossil plants from the Anthracite coal fields of Eastern Pennsylvania. Pennsylvania Geological Survey (4th Series). General Geological Report 72, $157 \mathrm{p}$.

Paxton, S. T. (1983) Relationships between Pennsylvanianage lithic sandstone and mudrock diagenesis and coal rank in the Central Appalachians. Ph.D. dissertation, The Pennsylvania State University.

Peters, K. E., Sweeney, R. E. and Kaplan, I. R. (1978) Correlation of carbon and nitrogen stable isotope ratios in sedimentary organic matter. Limnology and Oceanography 23, 598-604.

Philips, T. L., Peppers, R. A. and DiMichele, W. A. (1985) Stratigraphic and interregional changes in Pennsylvanian coal-swamp vegetation: Environmental inferences. International Journal of Coal Geology 5, 43 110.

Prasalov, E. M., Subbotin, Y. S. and Tikhomirov, V. V. (1990) Isotope composition of molecular-nitrogen in USSR natural gases. Geochemistry International 28, 1122.

Rigby, D. and Batts, B. D. (1986) The isotopic composition of nitrogen in Australian coals and oil shales. Chemical Geology 58, 273-282.
Rohrback, B. G., Peters, K. E., Sweeney, R. E. and Kaplan, I. R. (1983) Ammonia formation in laboratory simulated thermal maturation: implications related to the origin of nitrogen in natural gas. In Advances in Organic Geochemistry 1981, eds. M. Bjoroy et al., pp. 819-823. John Wiley and Sons.

Shapiro, N. and Gray, R. J. (1966) Physical variations in highly metamorphosed Antarctic coals. In Advances in Chemistry Series, ed. R. F. Gould, pp. 196-211. American Chemical Society Publication, Washington D.C.

Scholten, S. O. (1991) The distribution of nitrogen isotopes in sediments. Ph. D. dissertation, Utrecht University.

Scotese, C. R., Bambach, R. K., Barton, C., Van Der Voo, R. and Ziegler, A. M. (1979) Paleozoic base maps. Journal of Geology 87, 217-277.

Shearer, G. and Kohl, D. H. (1993) Natural abundance of ${ }^{15} \mathrm{~N}$ : Fractional contribution of two sources to a common sink and use of isotope discrimination. In Nitrogen Isotope Techniques, eds. R. Knowles and T. H. Blackburn, pp. 89-124. Academic Press.

Sohns, E., Gerling, P. and Faber, E. (1994) Improvements in stable isotope determinations on natural gases. Analytical Chemistry 66, 2614-2620.

Stach, E., Mackowsky, M. Th., Teichmuller, M., Taylor, G. H., Chandra, D. and Teichmuller, R. (1982) Textbook of Coal Petrology. Borntraeger, Stuttgart, p. 482.

Stadler, G. and Teichmuller, R. (1971) Zusammenfassender Uberblick uber die Entwicklung des Bramscher Massives und des Niedersachsischen Tektogens. Fortschritte in der Geologie von Rheinland und Westfalen 18, 547-564.

Suggate, R. P. (1959) New Zealand coals, their geological setting and its influence on their properties. Bulletin of New Zealand Department of Sciences Industry Ressources 13, 113 p.

Teichmuller, M. and Teichmuller, R. (1950) Das Inkohlungsbild des Niedersdchsischen Wealdenbeckens. Zeitschrift der deutschen geologischen Gesellschafi 100, 498517.

Volkova, I. B. and Bogdanova, M. V. (1989) Properties of high-rank coals and dispersed organic matter of associated rocks in the Donets Basin (USSR). International Journal of Coal Geology 11, 315-339.

Westgate, L. M. and Anderson, T. F. (1984) Isotopic evidence for the origin of sulfur in the Herrin (No. 6) coal member of Illinois. International Journal of Coal Geology 4, 1-20.

Wilks, K. R., Mastalerz, M., Bustin, R. M. and Ross, J. V. (1993) The role of strain in the graphitization of high volatile bituminous and anthracitic coals. International Journal of Coal Geology 22, 247-277.

Williams, L. B., Ferrell, R. E. Jr., Hutcheon, I., Bakel, A. J., Walsh, M. M. and Krouse, H. R. (1995) Nitrogen isotope geochemistry of organic matter and minerals during diagenesis and hydrocarbon migration. Geochimica et Cosmochimica Acta 59, 765-779.

Wintsch, R. P., O'Connell, A. F., Ranson, B. L. and Wiechmann, M. J. (1981) Evidence for the influence of $\mathrm{kn}$., on the crystallinity of disseminated carbon in greenschist facies rocks, Rhode Island, U.S.A.. Contribution to Mineralogy and Petrology 77, 207-213.

Wnuk, C. (1985) The ontogeny and paleoecology of Lepidodendron rimosum and Lepidodendron bretonense trees from the Middle Pennsylvanian of the Bernice basin (Sullivan County, Pennsylvania). Palaeontolographia 195B, 153-181.

Wnuk, C. (1989) Ontogeny and palaeoecology of the Middle Pennsylvanian arborescent lycopod Bothrodendron punctatum, Bothrodendraceae (Western 
Middle Anthracite field, Shamokin Quadrangle, Pennsylvania). American Journal of Botany 76, 966-980. Wnuk, C. and Pfefferkorn, H. W. (1987) A Pennsylvanian age terrestrial storm deposit: Using plant fossil to characterize the history and process of sediment ac- cumulation. Journal of Sedimentary Petrology 57, 212221.

Zhang, Y. and Zindler, A. (1993) Distribution and evolution of carbon and nitrogen in earth. Earth and Planetary Science Letters 117, 331-345. 